\title{
4: $122975781-122946753$
}

National Cancer Institute

\section{Source}

National Cancer Institute. 4:122975781-122946753. NCI Thesaurus. Code C41696.

Physical location of ANXA5_Gene 